\title{
Methodical requirements for training materials of on-line courses on the platform "Higher school mathematics teacher"
}

\author{
Kateryna Vlasenko ${ }^{1}$, Olena Chumak $^{2, *}$, Iryna Lovianova $^{3}$, Daria Kovalenko $^{4}$, and Nataliia Volkova $^{5}$ \\ ${ }^{1}$ Donbas State Engineering Academy, 7 Academic Str., Kramatorsk, 84313, Ukraine \\ ${ }^{2}$ Donbas National Academy of Civil Engineering and Architecture, 14 Lazo Str., Kramatorsk, 84333, Ukraine \\ ${ }^{3}$ Kryvyi Rih State Pedagogical University, 54, Gagarina Ave., Kryvyi Rih, 50086, Ukraine \\ ${ }^{4}$ The Institute of Chemical Technologies of Volodymyr Dahl East Ukrainian National University (the town of Rubizhne), \\ 31 Vladimirskaya Str., Rubizhne, 93009, Ukraine \\ ${ }^{5}$ Alfred Nobel University, 18 Naberezhna Sicheslavska Str., Dnipro, 49000, Ukraine
}

\begin{abstract}
The article looks into the issue of developing methodical requirements for the structure and content of online courses. The study is dedicated to the analysis of peculiarities of developing the content of online systems and developing methodical recommendations to educational materials for online courses of training higher school mathematics teachers. The research considers the experts' experience in preparing, structuring and developing the content for online courses and answers to volunteers who have agreed to test the educational materials of the course. The answers given by the participants have allowed estimating the quality of the developed course and detecting its insignificant drawbacks. The article discusses general requirements to the structure and content of the online course, means for the implementation of a testing subsystem, peculiarities of developing educational video content and educational materials in PDF format, issues of implementing forum and survey subsystems, as well as means of estimating learning outcomes. We have grounds to conclude that the quality of the course is determined by the range of factors, among which we point out the course organization based on weekly planning, implementation of a testing subsystem under conditions of extended functionality, creation of abilities to organize feedback.
\end{abstract}

\section{Introduction}

\subsection{Problem statement and its topicality substantiation}

Achieving sustainable development through on-line education is the key to a better and more sustainable future for everyone. The implementation of the idea of open online education requires the development of recommendations both as technical and methodical support of online courses; and thanks to them a considerable number of people can increase their qualification or develop professional expertise. Supporting the idea of available educational opportunities, we have created the educational platform Higher School Mathematics Teacher [1] that offers mathematical and educational - methodical online courses and we have studied experts' experience in preparing educational materials. By implementing numerous recommendations concerning the preparation, structuring, and development of the content for online courses, Writing and Structuring Online Learning Materials [2], DIGICOMP [3] and Leicester Learning Institute [4] remind that we live the life of constant changes and these changes have to influence teaching and learning. In order to implement these changes in the system of online education, we have to provide educational materials that live up to the students' expectations. This means that giving learners the possibility to acquire some particular skills via online courses requires serious training. Therefore, the actuality of the problem of developing methodical requirements for the structure and content of online courses is not questionable.

\subsection{Analysis of the latest researches and publications}

In order to start the development of online course "Methods for teaching mathematics to students in technical universities" [5], we have studied practical recommendations by B. Ghirardini [6] who considers that the development of any course has to encourage the creation of a community of practitioners and support their willingness to cooperate. While planning the development of materials necessary for implementing particular kinds of work we paid our attention to the possibility to plan the achievement of educational outcomes. At the stage of planning the aims, we were focused on the concept of the platform Higher School

* Corresponding author: chumakelena17@gmail.com 
Mathematics Teacher, developed by K. Vlasenko et al [7]. Taking into account scientists' opinion while preparing curriculum we were focused on achievable goals, believing that the achievement of aims by the student on a regular basis will encourage their motivation to aspire to more. While developing the lectures we were interested in the research by C. J. Dommeyer et al. [8], D. J. Deming et al. [9] and M. Bauer [10], who describe in their works the improvement of lecture materials using the questionnaire of respondents who work with courses. E. Cruse [11], A.-M. Suduc et al. [12, 13] recommend giving lectures using video. Confirming the efficiency of using videos in the educational process, among the greatest advantages of its using the scientists emphasize the possibility of course participants to learn the material according to their pace of assimilating the educational materials. Moreover, in scientists' works, there is evidence that video content ensures a greater emotional impact on participants in comparison to the text-based one. Developing tests that according to C. Suwatthipong et al. [14] have to accompany learning theoretical materials we considered scientists' opinion that testing should both help to estimate the level of success while assimilating the educational material and help to acquire new knowledge. Being acquainted with the research in which C. Wrigley et al. [15] compared the content quality of Massive Open Online Courses; we came to the conclusion that while developing course materials it is necessary to evenly distribute labour intensity of students' learning activities by weeks, providing the interaction among the participants. Furthermore, we took into consideration the results of the research by B.-A. Jönsson [16], and K. Vlasenko et al. [17], where it is justified that the efficient online course includes the integration of various web tools and resources for learning the course material.

Thus, giving recommendations to the presentation of educational materials for online courses, every scientist stated that there should its approach for the development and certain nuances should be considered. So, the article is aimed at carrying out a theoretical analysis of the peculiarities developing online system content and methodical requirements to educational materials for online courses of training higher school mathematics teachers.

\section{Method}

We have carried out a survey among master students (the qualification code of the program "014.04. Secondary Education. Mathematics") and higher school mathematics teachers to find out the quality of educational materials of online course "Methods for teaching mathematics to students in technical universities", published on the platform "Higher School Mathematics Teacher" [5]. The theoretical analysis of the researches and resources that implement the recommendations, content structuring and development for online courses and analysis of respondents' answers to survey questions published on the platform forum has influenced the description of the methodical requirements to structure and content of online courses. To explore the resources (Table 1), we used the Inductive Content Analysis Method, which helped us review the structure and content of the most popular Massive Open Online Courses (MOOC). When selecting resources, we focused on the online courses included in the Top Tools for Learning 2019 [18].

Having analysed the resources, we found out the number of sections that the on-line courses include and the average course duration. We were eager to know how often titles are offered and for what purpose testing in courses is used. We have highlighted the peculiarities of video lectures, training materials in PDF format. Particular attention was paid to how feedback from students, taking the course is organized. Through content analysis, we have developed methodical requirements for educational materials for online courses of training higher school mathematics teachers.

\subsection{General requirements to the structure and content of the online course}

Following the recommendations of dividing online course content into sections, subsections (topics), pages and components, we have built a course "Methods for teaching mathematics to students in technical universities" based on weekly planning, where sections are formed on the principle of combining materials that are learned during one or several weeks.

We have also considered that educational methodical online courses have to include no more than 6 sections. Every section has to include one or more pages; the page has to have no more than one component. In addition, while developing the courses we stuck to the following recommendations related to their structure.

1. We divided the materials of the course into logical sections of the length corresponding to learning during 1-2 hours ("blocks" of education).

2. For every section, subsection and page we gave clear descriptive headings. It will help students to plan over which sections they will work in every chapter and allow them to review the topics that have already been studied.

3. At the beginning of every week and every new section we gave a review of materials including structure, learning outcomes and approximate learning time. In addition, we gave the previous test at the beginning of every section.

\subsection{The implementation of the testing subsystem}

In order to implement the testing subsystem on the platform a program application for extending functionality was used - the plugin "WP-Pro-Quiz" that ensures flexible settings of responses' options and provides related information.

While creating test questions it is stipulated that information about the number of points for the right answer is provided and the type of answer (single choice, 
multiple-choice, open choice, etc.) is indicated. Also, there is a possibility to add hints to a particular question. After creating and setting up the test it is possible to publish it on any page of the online course using special shortcodes.
During the online course, the test is considered passed in case of giving $60 \%$ right answers by the participant.

After the test the participant can look through the number of right answers and time spent on taking it.

Table 1. Analysis of the structure and availability of educational materials of MOOC.

\begin{tabular}{|c|c|c|c|c|c|c|c|}
\hline $\begin{array}{c}\text { Online cour- } \\
\text { ses }\end{array}$ & $\begin{array}{c}\text { The number } \\
\text { of sections } \\
\text { that the on- } \\
\text { line course } \\
\text { includes }\end{array}$ & $\begin{array}{c}\text { Average } \\
\text { course } \\
\text { duration, } \\
\text { hours }\end{array}$ & $\begin{array}{c}\text { Titles are } \\
\text { used }\end{array}$ & $\begin{array}{c}\text { The availability of sub- } \\
\text { systems for testing }\end{array}$ & $\begin{array}{c}\text { The availabili- } \\
\text { ty of the video } \\
\text { lectures }\end{array}$ & $\begin{array}{c}\text { The availability } \\
\text { of educational } \\
\text { materials in } \\
\text { PDF format }\end{array}$ & $\begin{array}{c}\text { The availabili- } \\
\text { ty of commu- } \\
\text { nications tools }\end{array}$ \\
\hline $\begin{array}{c}\text { LinkedIn } \\
\text { Learning } \\
\text { [Lynda] [19] }\end{array}$ & $4-7$ & $2-28$ & $\begin{array}{c}\text { For every } \\
\text { section }\end{array}$ & $\begin{array}{c}\text { For evaluating the } \\
\text { learners' achievement }\end{array}$ & $\begin{array}{c}\text { For presenting } \\
\text { theoretical } \\
\text { material }\end{array}$ & Not used & Feedback form \\
\hline Udemy [20] & $4-12$ & $18-40$ & $\begin{array}{c}\text { For every } \\
\text { section }\end{array}$ & $\begin{array}{c}\text { For a current check on } \\
\text { the learners' practical } \\
\text { skills }\end{array}$ & $\begin{array}{c}\text { For presenting } \\
\text { theoretical and } \\
\text { practical } \\
\text { material }\end{array}$ & $\begin{array}{c}\text { For presenting } \\
\text { training tasks }\end{array}$ & Feedback form \\
\hline Coursera [21] & $4-6$ & $10-30$ & $\begin{array}{c}\text { For every } \\
\text { section, } \\
\text { subsection }\end{array}$ & $\begin{array}{c}\text { For evaluating the } \\
\text { learners' achievement }\end{array}$ & $\begin{array}{c}\text { For presenting } \\
\text { theoretical } \\
\text { material }\end{array}$ & $\begin{array}{c}\text { For presenting } \\
\text { training tasks }\end{array}$ & Forum \\
\hline edX [22] & $4-5$ & $12-20$ & $\begin{array}{c}\text { For every } \\
\text { section, } \\
\text { subsection } \\
\text { and page }\end{array}$ & $\begin{array}{c}\text { For a current check on } \\
\text { the learners' practical } \\
\text { skills }\end{array}$ & $\begin{array}{c}\text { For presenting } \\
\text { theoretical } \\
\text { material }\end{array}$ & $\begin{array}{c}\text { For presenting } \\
\text { theoretical } \\
\text { material and } \\
\text { training tasks }\end{array}$ & Forum of the \\
week
\end{tabular}

\subsection{Peculiarities of developing educational video content}

According to the recommendations, materials of the online course can consist of video files, hypertext, demonstrative animation, audio lectures, video lectures, schemes, images, graphics, tables, drawings, information reference material, computer simulators. Also, presentations and other extra materials such as attached files and interactive supplements, sources that are given in the reference list can be used.

We use video content to get participants acquainted with the aims and resources of the course as well as highlight particular topics. Video lectures focus on the main moments of learning material, disclose the topic of the material, and summarize the main conclusions. While creating video lectures it is expected to highlight semantic blocks (video clips) lasting from 3 to 10 minutes that will be watched by the participants during the online course. The image should be high -quality, the text that is demonstrated on the slides should be available for reading from the mobile device screen. Pure sound requires minimal background noise, clear pronunciation of words and constant level of volume. While creating video lectures it is preferable to use the universal format of video files in MP4 format.

In order to create videos during the online course "Methods for teaching mathematics to students in technical universities", we used software Camtasia which implements capturing the video from the screen. Among the main functional abilities of this video editor, which is used while developing educational video, we can highlight providing the recording of the image from the screen including recording sound effects from the microphone or speakers and editing a new video without installing additional software.

In order to publish video content on pages of the online course, we used the video from the file directly on the administrator's panel of the electronic platform without involving extra services. Using such a method of integration ensures the possibility to control the size of the video player and to add extra settings.

\subsection{Peculiarities of developing educational materials in PDF format}

In order to give the main theoretical information on the topics during the online course, we use educational materials in PDF format that ensures compatibility and absence of distortions in published materials of the course. Moreover, using PDF format allows the participants to download educational materials to their proper computers for a further acquaintance without any preview on the web-page.

While creating educational materials in PDF format it's necessary to follow the requirements for presenting documents: to use headings, lists, images with sighs, to present table data in the form of tables. In order to type text material the direct (regular) font, which ensures 
easier perception of information, should mainly be used. The main text should be aligned to the page width. It is not recommended to use formatting with the help of indent and tabulation, multi-column page making, blank line.

While using hyperlink it is necessary to consider that all hyperlinks should be represented as a text in the sentence to increase readability.

It must be noted that while preparing educational materials published on the platform during online courses, we use the logo of the public organization "Smart Maths".

\subsection{Forum implementation}

During the course "Methods for teaching mathematics to students in technical universities", the feedback with course participants is organized using thematic forums. Participants' part in the weekly forum gives them a possibility to express their proper opinion using discussion questions that concern the main topics of the course.

Together with the forum use the organization of participants' communication takes place in asynchronous mode, in other words during a long period. Participants can sign up for the forum to get notifications about new topics and answers on the forum. With the help of the forum, there is a participants' discussion of their classmates' works, which is outlined by one of the course tasks. Furthermore, participants can use the forum to share examples of their work and to ask each other questions and the teacher concerning the studied topics.

Forum implementation on the platform "Higher School Mathematics Teacher" was carried out using plugin "wpForo" that consists of a set of the main tools for managing the forum. The main advantages of using the plugin are flexible settings of the forum presentation, creation of convenient user's profile and the possibility to add particular supplements to extend the functionality.

\subsection{The implementation of the survey subsystem}

An important element while developing an online course is using surveys that ensure the teacher's possibility to ask participants questions and offer a wide range of possible answers. While creating a survey the teacher describes a certain situation and formulates a question encouraging participants to express their opinion. The survey final result is the percentage of participants who chose one or another answer.

During the course "Methods for teaching mathematics to students in technical universities", surveys are created with the help of service Google Forms and are used as voting for theme selection as well as for discussion over course materials.

The choice of Google Forms as a tool for creating surveys is explained by the following characteristics: availability of the created survey for the respondents just after its publication, possibility to edit it, opening for getting answers and closing after finishing the survey.
Furthermore, there is a possibility to integrate forms for surveys on the online course page. In order to show the survey results the service generates automatically the electronic table, there is an option to review respondents' answers in the form of diagrams and graphics with statistical information in high-quality and percentage format.

\subsection{Peculiarities of evaluating educational outcomes}

Within the course "Methods for teaching mathematics to students in technical universities", we assume to have peer assessment to estimate the performance of training activities. While using such type of evaluation, we followed the recommendations regarding the development of the criteria table. We took into account that requirements to tasks have to be clearly defined and encourage the author (later reviewer) to pay attention to different sides of work. The process of writing a piece of work that corresponds to the requirements and the process of checking such works is useful for participants, as it develops skills of giving constructive criticism including negative.

For every task, the course tutor developed the evaluation criteria with a detailed description of the necessary content on every criterion for getting a particular mark. As a tool we offer to use Google Drive services to complete the task; it ensures the possibility to store completed works by implementing shared access to the documents and Google Forms to implement the feedback with participants.

Successful learning of the educational material of the course is completed by getting a certificate. The criteria of getting a certificate are based on criteria - oriented approach that includes the comparison of educational achievements of every participant with planned learning outcomes.

\section{Results}

To carry out the analysis of the correspondence level of the course content "Methods for teaching mathematics to students in technical universities" to specified requirements of developing online courses, we held a survey among the participants. Respondents were offered to answer a survey using the forum on the platform "Higher School Mathematics Teacher".

68 volunteers who agreed to test educational materials of the course took part in the survey. Participants' answers allowed evaluating the quality of the developed course and determining minor gaps in the implementation.

We offered them to range the quality of presenting information concerning the structure and semantic content of the online course on a scale from 1 to 5 where 1 is the minimal parameter estimate, 5 is the maximal one. Table 2 provides the survey results.

Analyzing the histogram data we concluded that most volunteers have highly estimated the structure and quality of the developed content of online courses giving 
4 or 5 points. In respondents' opinion presenting information concerning the course program, its duration and frequency of classes were fulfilled most successfully. Among the types of educational content materials in PDF format and video lectures got the biggest number of maximal points. So, presentation of the structure of the online course and quality of developed educational materials correspond to given requirements.

Table 2. Results of testing educational materials of the course "Methods for teaching mathematics to students in technical universities".

\begin{tabular}{|l|r|c|c|c|c|}
\hline \multirow{2}{*}{ Questions } & \multicolumn{5}{|c|}{ Respondents' } \\
\cline { 2 - 6 } & $\mathbf{1}$ & $\mathbf{2}$ & $\mathbf{3}$ & $\mathbf{4}$ & $\mathbf{5}$ \\
\hline $\begin{array}{l}\text { Accessibility of information presentation } \\
\text { concerning the aims and purposes of the } \\
\text { course }\end{array}$ & 5 & 8 & 10 & 27 & 18 \\
\hline $\begin{array}{l}\text { Accessibility of information presentation } \\
\text { concerning the duration and frequency of the } \\
\text { course }\end{array}$ & 3 & 4 & 13 & 23 & 25 \\
\hline $\begin{array}{l}\text { Accessibility of information presentation } \\
\text { concerning the target audience of the course }\end{array}$ & 6 & 3 & 11 & 28 & 20 \\
\hline $\begin{array}{l}\text { Accessibility of information presentation } \\
\text { concerning the course program }\end{array}$ & 1 & 6 & 9 & 25 & 27 \\
\hline $\begin{array}{l}\text { Convenience of the navigation system } \\
\text { during the course }\end{array}$ & 8 & 9 & 15 & 24 & 12 \\
\hline $\begin{array}{l}\text { Quality of presenting educational materials } \\
\text { as video lectures }\end{array}$ & 1 & 4 & 7 & 29 & 27 \\
\hline $\begin{array}{l}\text { Quality of presenting educational materials } \\
\text { in PDF format }\end{array}$ & 2 & 6 & 12 & 23 & 25 \\
\hline Quality of tests & 3 & 5 & 14 & 26 & 20 \\
\hline $\begin{array}{l}\text { Quality of survey implementation among } \\
\text { course participants }\end{array}$ & 4 & 7 & 16 & 21 & 20 \\
\hline Quality of peer-assessment implementation & 4 & 8 & 14 & 20 & 22 \\
\hline $\begin{array}{l}\text { Quality of feedback implementation using } \\
\text { the weekly forum }\end{array}$ & 5 & 8 & 18 & 19 & 18 \\
\hline
\end{tabular}

The ranking results are presented in the form of a histogram (Fig. 1).

Moreover, participants were offered to evaluate general impression from the online course "Methods for teaching mathematics to students in technical universities" (Fig. 2).

According to the survey results, $68 \%$ of respondents believe that the course is developed at a high level, $25 \%$ have estimated the course development at a sufficient level and 7\% marked that the course requires further development. Among the recommendations given by the respondents concerning the improvement of the online course, we can note the wish to include the final test to evaluate the results of learning activities and modernization of navigation system to the course program.

\section{Discussion}

The analysis of the research by L. Cuesta [24], S. J. McGahan et al. [25] and work experience of APass Educational Group [26] developing online courses have confirmed our point of view about the influence of the quality of developing materials for online courses on motivation and success during the course. We agree with the point of view given by L. Cuesta [24] who emphasizes the necessity of constant analysis and evaluation of such parameters as the formation of learning content, interaction among course participants. We support the conclusions given by S.J. McGahan et al. [25] about the importance of developing methodical requirements to the content of online courses as the main tool of its quality evaluation.

The recommendations provided by the APass Educational Group [26] are very important for our research; they offer to provide the efficiency of the educational aim of the course using the following means: clear purpose presentation; match of the aim with students' expectations; direct responsibility between educational aims and students' actions during the course and their evaluation; learning materials selection and technologies that correspond to the education aims, motivate the student and support their progress; content accessibility for all students.

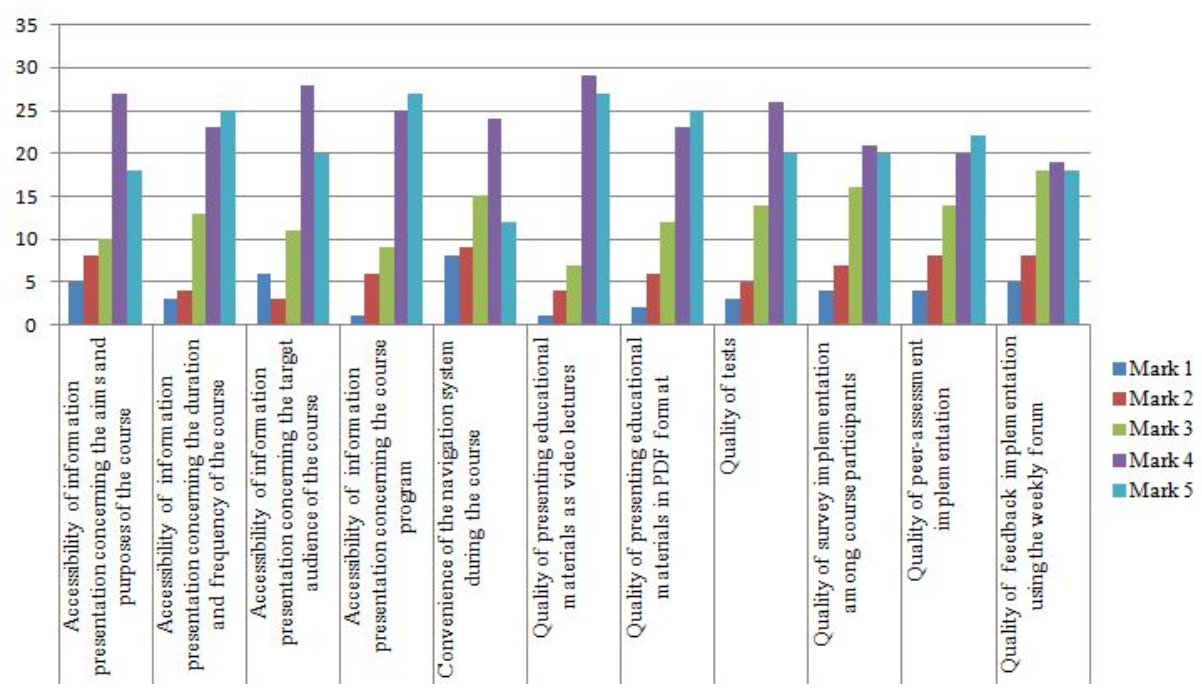

Fig. 1. Results of testing educational materials of the course "Methods for teaching mathematics to students in technical universities". 


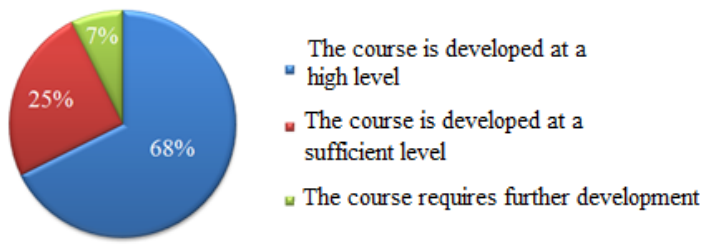

Fig. 2. The general impression from the online course "Methods for teaching mathematics to students in technical universities".

We have got acquainted with the accomplishments by N. I. Scagnoli et al. [27], D. Morrison [28], M. Puzziferro and K. Shelton [29] when we started developing video lectures. These scientists' works are dedicated to studying students' point of view concerning the use of video lectures in online classes. So, during the development of video lectures we were focused on scientists' recommendations. These recommendations were the following: to consider students' needs; to plan thoroughly and integrate in a balanced way video lectures with other course materials; to use multimodal information delivery; to create the sense of cooperation with the content through students' control over the media and teachers' presence.

Acquaintance with students' evaluation via Camtasia [30] as one of the most available programs of editing and creating video has proved the relevance of the choice of this program for presenting course content. Screen recording with the addition of necessary effects helped us in a quality new presentation and documents in PDF format. The involvement of such type of materials got approval from forum participants. During the course presentation and every week, we encourage students to take an active part in forums. This approach corresponds to the conclusions given by $\mathrm{T}$. Martin-Blas and A. Serrano-Fernandez [31], who prove that participants who take an active part in forum discussions tend to get higher marks and show a higher level of learning educational material in comparison to those who did not use the forum.

\section{Conclusions}

The relevance of the problem of developing methodical requirements to the structure and content of online courses arises from the fact that the quality of education using online courses depends on the quality of content development. Educational materials have to be interesting, correspond to students' expectations and encourage motivation during the course. The content development requires thorough planning and balanced integration with other course materials. Testing during the course should have both controlling and educational functions. The creation of course content should be accompanied by evaluation of students who help to evaluate the quality of the developed educational materials and detect gaps.

Based on the analysis of current recommendations regarding the development of online courses, as well as considering the results of students' and mathematics teachers' survey we have described the methodical requirements to the structure and content of online courses. The course is based on weekly planning, the test subsystem is implemented under extended functionality, and abilities to organize feedback are integrated. While planning online courses it is necessary to plan properly and organize feedback with course participants. The feedback allows detecting both positive aspects and gaps, drawbacks that were detected during project planning and implementation.

The possible way of implementing feedback is the creation of several theme forums where there is a possibility to exchange information among the listeners.

The results give a possibility to define several directions for further research, among which the implementation of online resources usability. survey.

We are grateful to everyone who has taken part in the

\section{References}

1. Higher School Mathematics Teacher (2019), http://formathematics.com. Accessed 21 Nov 2019

2. Writing and Structuring Online Learning Materials (Leicester Learning Institute, 2019), https://www2.le.ac.uk/offices/lli/case-studies-andresources/repository/learning-and-teachingresources/writing-and-structuring-online-learningmaterials-pdf. Accessed 21 Nov 2019

3. The methodology for preparation of materials for online courses (2019), http://www.aereform.si/DIGICOMP/Methodology.p df. Accessed 21 Nov 2019

4. Leicester Learning Institute (2019), https://www2.le.ac.uk/offices/lli. Accessed 21 Nov 2019

5. Methods for teaching mathematics to students in technical universities (2019), http://formathematics.com/courses/instruction-andmethodology-trainings/method-of-trainingmathematics-at-higher-technical-school/. Accessed 21 Nov 2019

6. B. Ghirardini. E-learning methodologies. A guide for designing and developing e-learning courses, (Food and Agriculture Organization of the United Nations, Rome, 2011)

7. K. Vlasenko, O. Chumak, I. Sitak, I. Lovianova, O. Kondratyeva, Training of mathematical disciplines teachers for higher educational institutions as a contemporary problem. Universal Journal of Educational Research 7(9), 1892-1900 (2019). doi:10.13189/ujer.2019.070907

8. C.J. Dommeyer, P. Baum, R.W. Hanna, K.S. Chapman, Gathering faculty teaching evaluations by in class and online surveys: their effects on response rates and evaluations. Assessment \& Evaluation in Higher Education 29(5), 611-623 (2004). doi:10.1080/02602930410001689171 
9. D.J. Deming, C. Goldin, L.F. Katz, N. Yuchtman, Can online learning bend the higher education cost curve? American Economic Review 105(5), 496501 (2015). doi:10.1257/aer.p20151024

10. M. Bauer, Translating a successful lecture into online course content - experiences of a control engineering lecturer. IFAC PapersOnLine 52(9), 272-277 (2019). doi:10.1016/j.ifacol.2019.08.220

11. E. Cruse, Using educational video in the classroom: theory, research and practice (Library Video Company, 2019),

http://www.libraryvideo.com/articles/article26.asp. Accessed 21 Nov 2019

12. A.-M. Suduc, M. Bizoi, F. Filip, Decision support systems for partnership activities facilitation. IFAC Proceedings J. 43(8), 59-62 (2010). doi:10.3182/20100712-3-FR-2020.00010

13. A. Suduc, M. Bîzoi, G. Gorghiu, L. Gorghiu, Digital images, video and web conferences in education: A case study. Procedia - Social and Behavioral Sciences 46, 4102-4106 (2012). doi:10.1016/j.sbspro.2012.06.207

14. C. Suwatthipong, C. Thangkabutra, N. Lawthong, A proposed model of knowledge sharing to develop educational, computer standardized test in higher education. Procedia - Social and Behavioral Sciences 191, 93-97 (2015). doi:10.1016/j.sbspro.2015.04.253

15. C. Wrigley, G. Mosely, M. Tomitsch, Design thinking education: A comparison of massive open online courses. She Ji: The Journal of Design, Economics, and Innovation 4, 275-292 (2018). doi:10.1016/j.sheji.2018.06.002

16. B.-A. Jönsson, A case study of successful elearning: a web-based distance course in medical physics held for school teachers of the upper secondary level. Medical Engineering and Physics 27(7), 571-581 (2005). doi:10.1016/j.medengphy.2004.11.009

17. K. Vlasenko, S. Volkov, D. Kovalenko, I. Sitak et al, Web-based online-course training higher school mathematics teachers. CEUR Workshop Proceedings (2020, in press)

18. Top Tools for Learning 2019 (2019), http://c4lpt.co.uk/directory-of-learningperformance-tools/collections-of-online-coursesand-resources/. Accessed 18 Dec 2019

19. LinkedIn Learning [Lynda] (2019), https://www.linkedin.com/learning. Accessed 18 Dec 2019

20. Udemy (2019), https://www.udemy.com/. Accessed 18 Dec 2019

21. Coursera (2019), https://www.coursera.org/. Accessed 18 Dec 2019

22. EdX (2019), https://www.edx.org/. Accessed 18 Dec 2019

23. FutureLearn (2019), https://www.futurelearn.com/. Accessed 18 Dec 2019
24. L. Cuesta, Profile 12(1), 181 (2010)

25. S.J. McGahan, C.M. Jackson, K. Premer, InSight: A Journal of Scholarly Teaching 10, 126 (2015)

26. APass Educational Group.LLC. Quality matters: A guide to online course development standards (2019), https://apasseducation.com/educationblog/quality-matters-online-course-standards/. Accessed 21 Nov 2019

27. N.I. Scagnoli, J. Choo, J. Tian, Students' insights on the use of video lectures in online classes. British Journal of Educational Technology 50(1), 399-414 (2019). doi:10.1111/bjet.12572

28. D. Morrison, Seven must-read books about education: the 2017 list (Online Learning Insights, 2019), https://onlinelearninginsights.wordpress.com/author/ onlinelearninginsights/. Accessed 21 Nov 2019

29. M. Puzziferro, K. Shelton, A model for developing high-quality online courses: integrating a systems approach with learning theory. Journal of Asynchronous Learning Networks 12(3-4), 119-136 (2019). doi:10.24059/olj.v12i3.58

30. Quora. Why should I use Camtasia? (2019), https://www.quora.com/Why-should-I-useCamtasia. Accessed 18 Dec 2019

31. T. Martin-Blas, A. Serrano-Fernandez, The role of new technologies in the learning process: Moodle as a teaching tool in Physics. Computers \& Education 52, 35-44 doi:10.1016/j.compedu.2008.06.005
(2009). 